\title{
A Currency Union or an Exchange Rate Union: Evidence from Northeast Asia
}

\author{
Bang Nam Jeon and Hongfang Zhang \\ Drexel University
}

\begin{abstract}
This paper examines whether or not the Northeast Asian economies, namely, China, Japan, Korea, and Taiwan, can form a currency union, where a single currency and a uniform monetary policy are adopted, or an exchange rate union where all the currencies are pegged to an internal or external currency or an optimum currency basket. The analysis of correlations of supply shocks, exchange rate shocks, monetary shocks, and demand shocks, which are estimated applying the structural VAR model with identification restrictions imposed, to the data for the period from 1970 through 2004, shows that shocks of these economies are not symmetric, in general, implying that the Northeast Asian economies are not ready yet to form a common currency union. However, it is found that the Northeast Asian countries can form an exchange rate union with a major currency basket, which consists of the U.S. dollar, the euro and the Japanese yen, as an anchor currency. The paper also examines the option of pegging to a basket of regional currencies, similar to the Asian Currency Unit (ACU), and discusses policy implications.
\end{abstract}

- JEL classification: F33, F36

- Keywords : Currency union, Exchange rate union, Optimum currency areas, Northeast Asia

\footnotetext{
*Corresponding address: Bang Nam Jeon, Department of Economics and International Business Bennett S. LeBow College of Business Drexel University $32^{\text {nd }}$ and Market Streets Philadelphia, PA 19104, USA, Tel: +1-215-895-2125, Fax: +1-215-895-6975, E-mail: jeonbana@drexel.edu 


\section{Introduction}

This paper examines whether the Northeast Asian economies, namely, China, Japan, Korea, and Taiwan, can form a currency union where a single currency and a uniform monetary policy are adopted, or an exchange rate union where all the currencies are pegged to a single currency or a common currency basket. It also attempts to find a currency or an optimum currency basket for the Northeast Asian economies if an exchange rate union is feasible.

The experience of the Euro has rekindled interest in the possibility of a common currency area in East Asia. Before the Asian financial crisis in 1997, most East Asian countries adopted a fixed exchange rate regime or a managed floating regime, virtually pegging to the U.S. dollar. This dollar peg makes the exports of the countries, which compete with Japan for exports, fluctuate when the yen-dollar exchange rate changes. The volatility of the exchange rate between the Japanese yen and the U.S. dollar can lead to fluctuations in the income of the East Asian countries which compete with Japan, like Korea, Hong Kong, and Singapore. Many countries are forced after the crisis to float their exchange rates, which causes more fluctuations in exports and income. The crisis of 1997 makes more evident the importance of stability of the exchange rates among Asian countries. It also shows that the dollar peg seems to be risky for the East Asian countries. After learning this valuable lesson, the East Asian countries started to look for a more suitable exchange rate arrangement after the crisis.

The increasing financial and trade cooperation of the East Asian countries have also provided academia and policy-makers with an important momentum to evaluate the feasibility and a timetable, if possible, of forming a common currency area in East Asia. The finance ministers of the Association of Southeast Asian Nations (ASEAN) plus China, Japan, and Korea (ASEAN+3) agreed on the Chiang Mai Initiative (CMI) in May 2000, which provides foreign reserves to member countries facing a speculative attack. As of November 2005, the total amount of bilateral swap arrangements under the CMI is $\$ 58.5$ billion, more than $80 \%$ of which is provided by China, Japan and Korea. In 1992, ASEAN countries formed the ASEAN Free Trade Area (AFTA). This agreement facilitates intraregional trade and strengthens cooperation of the ASEAN countries. Japan established a partnership with the ASEAN in the AFTA. China also agreed to form the ASEAN-China Free Trade Area (ACFTA) with the ASEAN in 2002. Besides the CMI and the AFTA, ASEAN+3 also aim to promote the development of 
domestic bond markets and the creation of a regional bond market.

The Asia Development Bank (ADB) announced a plan to issue the Asian currency unit (ACU) in early 2006. The ACU is a statistical index, not a legal tender yet, based on a currency basket containing 10 ASEAN countries plus China, Japan and Korea. The weight of each currency is going to be determined by GDP and the trade volume of the country that uses this currency. The weights of the Chinese yuan, the Japanese yen and the Korean won are expected to be substantial. The introduction of the ACU is expected to help to stabilize the fluctuation of the 13 currencies in the region. The ACU is considered to be the first step toward a single currency in the region, although there would be a long way to go from the ACU to a single common currency. It needs the harmonious efforts and cooperation of governments and economic convergence in the region.

Along with these positive and forward-looking developments toward increasing monetary coordination in Asia, several studies have investigated the feasibility of forming an optimum currency area (OCA) in East Asia. The findings of the studies are mixed. Eichengreen and Bayoumi $(1994,1996)$ find that the East Asian countries satisfy several standard optimum-currency-area requirements for an OCA. Larraín and Tavares (2005) find that the level of economic integration of the East Asian countries is approaching that of the European countries. Bénassy-Quéré (1999), Chow and Kim (2003), Kwak (2004), and Lee and Barro (2006) find, however, that East Asia is still not ready for establishing an optimum currency area. Other authors find that only a few countries in the region are ready to form a currency area. ${ }^{1}$ There is not a consensus built yet on whether or not the East Asian countries as a whole can form a currency union.

Although the East Asian countries have increased financial and trade integration through swap agreements and free trade agreements, they have diverse economic structures, relatively isolated labor and financial markets, and different levels of economic development. Economic divergence makes it difficult for the East Asian economies to adopt a uniform monetary policy. Political and cultural factors are

${ }^{1}$ Bayoumi and Eichengreen (1994) suggest two common currency areas for East Asia. One is a Northeast Asian bloc including Japan, Korea and Taiwan, and the other one is a Southeast Asian bloc which includes Hong Kong, Malaysia, Singapore, and possibly Thailand. Their study does not include China. Karras (2005) finds that Korea and Indonesia are promising candidates for the yen bloc based on an analysis of costs and benefits. He does not examine the symmetry of shocks across counties. Huang and Guo (2006) propose a currency union including Hong Kong, Indonesia, Korea, Malaysia, Singapore, and Thailand. Lim (2005) finds that Hong Kong, Korea, Philippines, Singapore and Thailand can form a currency union. 
also expected to play a very important role in conducting monetary cooperation under a currency union. Countries such as Malaysia, Indonesia, Philippines and Thailand seem to be quite different from countries of China, Japan, and Korea in social structure and culture. Hong Kong is a special administrative area of China. It is unlikely that Hong Kong would join a currency area without co-ordination with the central government of China. It is less likely that all the East Asian countries can form a common currency area in a reasonably short time period.

China, Japan, Korea and Taiwan are important economies in East Asia. These Northeast Asian economies have become more integrated economically in recent years. They are major trading partners with each other. Taiwan's economic and trade relationships with China, Japan, and Korea are closer than those with the ASEAN countries. Is it possible for the four Northeast Asian countries, as an important sub-set of the East Asian nations, to form a currency union? This paper attempts to investigate the possibility of establishing a currency union or an exchange rate union in Northeast Asia which consists of China, Japan, Korea and Taiwan.

The remainder of this paper is organized as follows. Section II describes the background and rationales for introducing a currency union in Northeast Asia. Section III describes our econometric methodology for the analysis. Section IV describes data used for our study, and reports a summary of statistical characteristics of data and the results of preliminary tests on the data. Section V reports the empirical results on various options of a currency union and an exchange rate union in the region. Section VI provides a summary of the paper and discusses policy implications.

\section{Toward a Currency Union in Northeast Asia: Background and Rationale}

Since the 1980s, economic ties between China, Japan, Korea and Taiwan have kept increasing trade and capital flows among the four Northeast Asian countries. In 1991 the Northeast Asia Economic Forum (NEAEF) was created to promote research, networking and dialogue relevant to the economic and social development of Northeast Asia. The idea of the Northeast Asian Development Bank (NEADB) has been discussed since the establishment of NEAEF. A special committee for the establishment of the NEADB was created in 2000. This can be viewed as the first step toward the monetary unification among the Northeast 
Asian economies. Mutual benefits provide an important incentive for the Northeast Asian countries to cooperate with each other.

There are many studies investigating what economic characteristics the members of a common currency area should share (for example, Mundell, 1961; McKinnon, 1963; Kenen, 1969). The basic characteristic is that members of the common currency area should respond symmetrically to common shocks. Other criteria include factor mobility, trade openness, factor mobility, an increasing share of the intra-regional trade out of total trade, among others, as discussed below.

\section{A. Trade Openness}

China, Japan, Korea, and Taiwan have chosen the export-oriented economic growth strategy for their economic development. This development strategy increases the openness of their economies. The more open the economy is, the more its output is affected by changes in the currency value. A common currency or a collective peg helps to stabilize exchange rates, and then reduces fluctuations of trade balance and output. Table 1 illustrates changes in the degree of trade openness of the four Northeast Asian economies during 1980 through 2003. ${ }^{2}$ It shows that Japan is the least open and Korea is the most open. China's total trade as a percentage of GDP increased significantly during the period from 1980 to 2003. In 1980, the total trade volume of China was only $15 \%$ of GDP and in 2003, it increased to $66 \%$. China became the second most open country among the four economies after Korea (73\%) in 2003. The trade openness of Korea and Taiwan fluctuates over time, although they are the most open among the four.

Since its entry to the World Trade Organization (WTO) in 2001, China has cut import barriers significantly. China, Japan and the ASEAN countries have

Table 1. The degree of trade openness of the Northeast Asian economies

\begin{tabular}{cccccccccc}
\hline & 1980 & 1990 & 1995 & 1997 & 1998 & 2000 & 2001 & 2002 & 2003 \\
\hline China & 15.48 & 35.52 & 45.68 & 41.38 & 39.21 & 49.06 & 48.54 & 54.77 & 66.13 \\
Japan & 28.16 & 18.32 & 16.80 & 20.42 & 19.56 & 20.18 & 20.16 & 21.13 & 22.01 \\
Korea & 70.92 & 55.82 & 58.75 & 65.39 & 79.46 & 78.49 & 73.31 & 69.12 & 73.81 \\
Taiwan & - & 59.12 & 65.06 & 61.44 & 52.67 & 66.366 & 54.26 & 55.93 & 62.02 \\
\hline
\end{tabular}

Note: Data of China, Japan, and Korea are from the Development Indicator of World Bank. Openness of Taiwan is calculated using data from http://eng.stat.gov.tw and http://cus93.trade.gov.tw.

${ }^{2}$ Trade openness is defined as the total trade (imports plus exports) as a percentage of GDP. 
proposed to establish the ASEAN-China FTA and the ASEAN-Japan FTA within 10 years. Korea and the U.S. concluded KORUS FTA in April 2007. These efforts improve the openness of the Northeast Asian area, and it is expected to increase the benefits from a currency union or monetary cooperation in the region.

\section{B. Intra-regional Trade}

Countries can benefit from a common currency by keeping a stable exchange rate among its member countries when they have a significant amount of intraregional trade. The East Asian countries experienced a dramatic growth in the intra-regional trade since 1980. Table 2 lists the shares of trade with the major trading partners for China, Japan, Korea and Taiwan. The share of China in the trade of other economies has increased tremendously over time. China was ranked as $27^{\text {th }}$ in 1989 among all the trading partners of Taiwan, $12^{\text {th }}$ in 1997 , and third in 2003. In 2003, China was the $2^{\text {nd }}$ largest trading partner of Japan and Korea after the United Statess. The shares of Korea in China's and Taiwan's trade have increased over time. Japan is the largest trading partner of China and Taiwan, and the third largest trading partner of Korea. Accordingly, intra-regional trade has significantly increased over time.

Table 2. Shares of trade by trading partners (\%)

\begin{tabular}{cccccccccc}
\hline \multirow{5}{*}{ China } & 1991 & - & 14.96 & 2.47 & 0.44 & 17.87 & 10.44 & 10.42 & 61.27 \\
& 1997 & - & 18.71 & 7.39 & 1.40 & 27.50 & 15.08 & 10.68 & 46.74 \\
& 2003 & - & 15.69 & 7.43 & 3.80 & 26.92 & 14.87 & 12.25 & 45.96 \\
& & & & & & & & & \\
Japan & 1991 & 4.14 & - & 5.89 & 5.09 & 15.12 & 26.44 & 13.99 & 44.45 \\
& 1997 & 8.36 & - & 5.36 & 5.36 & 19.09 & 25.58 & 10.95 & 44.38 \\
& 2003 & 15.52 & - & 6.16 & 5.20 & 26.88 & 20.69 & 11.16 & 41.27 \\
& & & & & & & & & \\
Korea & 1991 & 2.35 & 23.31 & - & 2.12 & 25.74 & 27.78 & 11.10 & 21.17 \\
& 1997 & 8.16 & 14.76 & - & 2.56 & 25.48 & 17.96 & 9.18 & 47.38 \\
& 2003 & 15.35 & 14.42 & - & 3.57 & 33.34 & 15.96 & 9.58 & 41.12 \\
& & & & & & & & & \\
Taiwan & 1991 & 0.43 & 20.17 & 2.18 & - & 22.78 & 26.21 & 12.39 & 38.62 \\
& 1997 & 1.92 & 17.21 & 3.13 & - & 22.26 & 22.32 & 11.91 & 43.51 \\
& 2003 & 11.93 & 16.41 & 4.89 & - & 33.23 & 15.76 & 9.51 & 41.50 \\
\hline
\end{tabular}

Note: Shares of trade are calculated using data form Direction of Trade Statistics Yearbook, International Monetary Fund. Shares of trade of Taiwan are calculated using data from http://cus93.trade.gov.tw. 
For example, as shown in Table 2, the intra-regional trade of China and Japan have increased from a range of $15-18$ percent to 27 percent since the early 1990 s. The intra-regional trade of Korea and Taiwan has also increased from the 23-26 percent level to more than 33 percent during the period of 1991 through 2003. The increase in intra-regional trade among the Northeast Asian economies provides a more favorable environment to introduce a currency union in the region.

\section{Factor Mobility}

According to Mundell (1961), with free labor mobility, workers can move to other countries when a negative shock hits an economy, so that the increase in unemployment in the home country is relieved. Bayoumi and Eichengreen (1994) argue that the requirement of labor mobility is not that important because labor mobility even in many developed countries is not very high. Labor still cannot move freely within Northeast Asia, although its mobility has increased in recent years. China is a labor-exporting country, while Japan and Taiwan are laborimporting countries. The number of foreign workers has increased in the Northeast Asian region in recent years.

Another factor that moves among the economies is capital. Foreign Direct Investment (FDI) is an important channel of capital flows. FDI is essential for economic growth in the Northeast Asian economies, especially for China. About one-fifth of all FDI inflows to China is intra-regional FDI. Financial cooperation is active in this area, especially among China, Japan and Korea. In the implementation of the CMI swap agreement, China, Japan and Korea play very important roles. As of November 2005, more than $80 \%$ of the total amount of bilateral swap arrangements is provided by China, Japan, and Korea, and it covers the 10 ASEAN nations plus the three Northeast Asian countries.

\section{Business Cycle Synchronization and Symmetric Macroeconomic Shocks}

Business cycle synchronization is one of the crucial requirements for perspective member countries of a common currency area to introduce a common currency. The cost of adopting a single currency will be smaller if the business cycles of member countries are synchronized, because a uniform monetary policy can be applied effectively when they encounter common shocks. However, business cycle synchronization is not a sufficient condition for adopting a uniform monetary policy. Shocks should also be symmetric across economies. Countries with synchronized business cycles should not introduce a uniform monetary policy if 
they experience shocks mainly as country-specific, asymmetric shocks instead of common and symmetric shocks. Then they are not quite eligible to form a currency union. China, Japan, Korea, and Taiwan have become more open and more integrated in trade and finance since the early 1990s. Whether or not shocks are symmetric among the Northeast Asian economies determines if they are ready to form a common currency area. If they are facing similar shocks, the cost of relinquishing an independent monetary policy will be trivial.

One of the main focuses of this paper is to investigate whether or not the macroeconomic shocks in the economies of China, Japan, Korea and Taiwan are symmetric and correlated. If shocks are symmetric and correlated across the regional nations, the member countries are qualified to form a monetary union.

\section{Econometric Methodology}

We set up the structural vector autoregression (SVAR) model to explore the pattern and cross-relations between various macroeconomic shocks in Northeast Asia. ${ }^{3}$ This is an extension of the framework of Bayoumi and Eichengreen (1994) from a two-variable model to a four-variable model by incorporating exchange rate shocks and monetary shocks. The Northeast Asian economies are export-oriented economies. Changes in exchange rates have a significant impact on the output of these economies by affecting imports and exports. The exchange rate is one of the key determinants of the competitiveness of their products in the global marketpalce. The symmetry and propagation of monetary shocks also play an important role in assessing the optimum currency area (OCA) criteria. If monetary shocks are symmetric across economies, the member countries can adopt a uniform monetary policy with smaller costs, and then forming a common currency area will be a favorable option for them.

\footnotetext{
${ }^{3}$ Other studies, which investigate whether or not shocks of different countries are correlated using structural vector autoregression (SVAR) models, include Chow and Kim, 2003; Kwack, 2004; Zhang, Sato, and McAleer 2004; Kim and Sun 2005; and Huang and Guo, 2006). Bayoumi and Eichengreen (1994) take into account demand and supply shocks among 15 European countries, 11 Asian countries, and 13 American countries. Kwack (2004) also uses demand and supply shocks for 10 East Asian countries. Chow and Kim (2003) consider global, regional, and domestic supply shocks for 7 East Asian countries. However, these studies are quite limited because they examine only demand and supply shocks in their analyses. Kim and Sun (2005) introduces fiscal shocks for the domestic economy and monetary shocks for the foreign economies. Huang and Guo (2006) extend to a four-variable system, which accounts for global supply shocks, domestic supply shocks, demand shocks and monetary shocks, for 9 East Asian countries.
} 
The Northeast Asian economies can be described using the following movingaverage representation of the SVAR model.

$$
\begin{aligned}
\Delta x_{t} & =A_{0} u_{t}+A_{1} u_{t-1}+A_{2} u_{t-2}+\ldots \\
& =A(L) u_{i}
\end{aligned}
$$

$\Delta x=\left[\Delta y, \Delta\left(e+p^{*}-p\right), \Delta(m-p), \Delta p\right] . e_{t}+p_{t}^{*}-p_{t}$ is the real exchange rate, and $m_{t}-$ $p_{t}$ is the real money balance. The model adopts five variables: output $\left(y_{t}\right)$, the nominal exchange rate $\left(e_{t}\right)$, nominal money $\left(m_{t}\right)$, domestic price $\left(p_{t}\right)$, and foreign price $\left(p_{t}^{*}\right)$. All series are in natural logarithms. D denotes the differenced series. $u_{t}=\left[u_{t}^{s}, u_{t}^{e}, u_{t}^{m}, u_{t}^{d}\right]$ is a vector of unobserved shocks: a supply shock $\left(u_{t}^{s}\right)$, an exchange rate shock $\left(u_{t}^{e}\right)$, a monetary shock $\left(u_{t}^{m}\right)$, and a demand shock $\left(u_{t}^{d}\right)$. It is assumed that these structural shocks are orthogonal to each other, i.e., $\mathrm{E}\left[u^{\prime} u\right]=\mathrm{I}$.

Equation (1) can be rewritten in matrix form,

$$
\left(\begin{array}{c}
\Delta y_{t} \\
\Delta\left(e_{t}+p_{t}^{*}-p_{t}\right) \\
\Delta\left(m_{t}-p_{t}\right) \\
\Delta p_{t}
\end{array}\right)=\left(\begin{array}{c}
A_{11}(L) A_{21}(L) A_{13}(L) A_{14}(L) \\
A_{21}(L) A_{22}(L) A_{23}(L) A_{24}(L) \\
A_{31}(L) A_{32}(L) A_{33}(L) A_{34}(L) \\
A_{41}(L) A_{42}(L) A_{43}(L) A_{44}(L)
\end{array}\right)\left(\begin{array}{c}
u_{t}^{s} \\
u_{t}^{e} \\
u_{t}^{m} \\
u_{t}^{d}
\end{array}\right)
$$

$(L)$ 's are polynomials in the lag operator $L$, representing the impulse response of output, the real effective exchange rate, real money balance, and inflation to various macroeconomic shocks.

Following Blanchard and Quah (1989), the following identifying restrictions to long-run effects are imposed to fully identify the structural model from the reduced-form VAR model.

First, demand shocks, monetary shocks and exchange rate shocks do not affect output in the long-run.

$$
\sum_{i=0}^{\infty} A_{12 t}(L)=0 ; \sum_{i=0}^{\infty} A_{13 i}(L)=0 ; \text { and } \sum_{i=0}^{\infty} A_{14 i}(L)=0 .
$$

Second, the real effective exchange rate is not affected by monetary shocks or demand shocks in the long-run. 


$$
\sum_{i=0}^{\infty} A_{23 i}(L)=0 \text {, and } \sum_{i=0}^{\infty} A_{24 i}(L)=0 .
$$

Third, real money balances are not affected by demand shocks in the long-run.

$$
\sum_{i=0}^{\infty} A_{34 i}(L)=0 .
$$

Therefore, Equation (2) becomes

$$
\left(\begin{array}{c}
\Delta y_{t} \\
\Delta\left(e_{t}+p_{t}^{*}-p_{t}\right) \\
\Delta\left(m_{t}-p_{t}\right) \\
\Delta p_{t}
\end{array}\right)=\left(\begin{array}{cccc}
A_{11}(L) & 0 & 0 & 0 \\
A_{21}(L) & A_{22}(L) & 0 & 0 \\
A_{31}(L) & A_{32}(L) & A_{33}(L) & 0 \\
A_{41}(L) & A_{42}(L) & A_{43}(L) & A_{44}(L)
\end{array}\right)\left(\begin{array}{c}
u_{t}^{s} \\
u_{t}^{e} \\
u_{t}^{m} \\
u_{t}^{d}
\end{array}\right)
$$

The structural shocks are not observed, but they can be recovered from a VAR estimation using the procedure proposed by Blanchard and Quah (1989). A reduced-form vector autoregression (VAR) for $\Delta x$ is estimated to obtain

$$
\begin{aligned}
\Delta x_{t} & =v_{t}+B_{1} v_{t-1}+B_{2} v_{t-2}+\ldots \\
& =B(L) v_{t}
\end{aligned}
$$

$v_{t}$ are residuals of the reduced-form VAR equation, and $\mathrm{e}\left[v^{\prime} v\right]=\Omega ; B(L)$ is a $4 \mathrm{x} 4$ coefficient matrix with elements equal to the polynomials $B_{i j}(L)$, and $B(0)=1$. To get equation (2'), residuals $v_{t}$ must be transformed into shocks, $u_{t}$. The relationships between the unobserved shocks of the SVAR model and the residual of the reduced-form VAR model can be derived from equation (1) and (3), which are $v_{t}=A_{0} u_{t}$, and $A_{j}=B_{j} A_{0}$ for all $j . A_{0}$ is identifiable when utilizing information from $A_{0} A_{0}{ }^{\prime}=\Omega$ and the long-run restrictions specified above, imposing the upper-righthand entry of $A(L)$ to be 0 . Then the unobserved disturbance is obtained as $u_{t}=A_{0}^{-1} v_{t}$.

We then calculated the correlation coefficients between shocks across economies. If the shocks are of similar patterns in the impulse-response relationship, and are positively and significantly correlated across the economies, they are viewed as symmetric. If they are idiosyncratic in each economy and are not correlated, the shocks are viewed as asymmetric. 


\section{Data and Preliminary Tests}

We use annual data for the four Northeast Asian economies during the period from 1970 to 2004 in this paper. ${ }^{4}$ Data on China, Japan, Korea, the U.S. and countries of the Euro area ${ }^{5}$ are obtained from different data sources. Real GDP, CPI, ${ }^{6}$ and M2 are taken from the Development Indicator of the World Bank. Exchange rate data are from the International Financial Statistics (IFS) of the International Monetary Fund (IMF). ${ }^{7}$ Trade data are collected from the Direction of Trade Statistics of IMF. Data of Taiwan are obtained from various websites of local statistical authorities. ${ }^{8}$ The variables for the Euro area before 1999 are estimated as the weighted average of all 12 countries. The weight is the average share of their GDP for the period from 1970-2004. We calculate the real effective exchange in the following way. First, the nominal exchange rates of each country are transformed into real exchange rates using the CPI of both countries. The real effective exchange rate is the geometric average of the real exchange rate of domestic currency against the U.S. dollar, the Japanese yen and the euro. The weight is the average share of trade for the period of 1990-2003. The shares of each currency for the four economies are listed in Table 3. It is shown that the U.S. dollar has the highest weight for Japan (70\%), Korea (43\%) and Taiwan (42\%). The Japanese yen has the highest weight for China (40\%). During the whole sample period, the real effective exchange rates of China, Korea, and Taiwan tend to increase, while the real effective exchange rates of Japan are shown to have decreased.

Before estimating the model, unit root tests ${ }^{9}$ are conducted to check whether or not the variables are of unit-root processes or stationary. All of the series are shown to be non-stationary in levels except the CPI of Japan. The logarithms of most

\footnotetext{
${ }^{4}$ Data for China covers the period from 1977 to 2004.

${ }^{5}$ The Euro area countries include Austria, Belgium, Finland, France, Germany, Greece, Ireland, Italy, Luxembourg, Netherlands, Portugal, and Spain.

${ }^{6}$ For China and Germany, there are no data for CPI. GDP deflator is used instead.

${ }^{7}$ The exchange rate data are the end-of-the-period basis.

${ }^{8} \mathrm{GDP}, \mathrm{CPI}$, and the exchange rate are downloaded from http://eng.stat.gov.tw; data of money aggregates from http://www.cbc.gov.tw; and data of international trade from http://cus93.trade.gov.tw.

${ }^{9}$ Augmented Dickey-Fuller tests are used.
} 
Table 3. The weight of each currency in real effective exchange rates of the Northeast Asian currencies

\begin{tabular}{lcccc}
\hline & China & Japan & Korea & Taiwan \\
\hline U.S. Dollar & 0.34 & 0.70 & 0.43 & 0.42 \\
Euro & 0.26 & 0.30 & 0.21 & 0.22 \\
Japanese yen & 0.40 & - & 0.36 & 0.36 \\
\hline
\end{tabular}

Note: Calculated using data from Direction of Trade Statistics, IMF.

series are non-stationary except for the logarithms of real GDP for Japan and Taiwan, and those of the CPI for Korea and Taiwan. Then, all data are transformed into the log-difference form to de-trend. The log differences of real GDP, the real effective exchange rate, and real money balance are stationary at the 5\% level. The log differences of CPI for China, Japan, and Taiwan are stationary, with an exception of Korea, at the $10 \%$ level.

Table 4 reports the mean and standard deviation of changes in the variables. Economic growth, real exchange rate changes, real money balance growth, and inflation are expressed as the changes in the logarithms of real GDP, real effective exchange rate, real money balance and CPI. The mean of real GDP growth shows that China enjoys the highest economic growth among the four economies, and the growth rate of Japan is the lowest. The standard deviation suggests that China and Japan have more stable growth than Korea and Taiwan. The real effective exchange rate of China has increased the fastest, which means that the Chinese yuan has depreciated faster than the other currencies during the sample period. The average rate of changes in the real effective exchange rate in Japan is negative,

Table 4. Summary statistics (log difference), 1970-2004

\begin{tabular}{|c|c|c|c|c|}
\hline & \multicolumn{2}{|c|}{ Real GDP Growth } & \multicolumn{2}{|c|}{ Real Effective Exchange Rate Changes } \\
\hline & Mean & Std. Dev. & Mean & Std. Dev. \\
\hline China & 0.0904 & 0.0263 & 0.0669 & 0.1403 \\
\hline Japan & 0.0300 & 0.0228 & -0.0064 & 0.1191 \\
\hline Korea & 0.0678 & 0.0357 & 0.0204 & 0.1588 \\
\hline \multirow[t]{3}{*}{ Taiwan } & 0.0709 & 0.0348 & 0.0156 & 0.1055 \\
\hline & \multicolumn{2}{|c|}{ Real Money Balance Growth } & \multicolumn{2}{|c|}{ Inflation } \\
\hline & Mean & Std. Dev. & Mean & Std. Dev. \\
\hline China & 0.1625 & 0.0663 & 0.0486 & 0.0499 \\
\hline Japan & 0.0416 & 0.0481 & 0.0331 & 0.0452 \\
\hline Korea & 0.1080 & 0.0723 & 0.0808 & 0.0652 \\
\hline Taiwan & 0.1160 & 0.0895 & 0.0458 & 0.0726 \\
\hline
\end{tabular}


implying that the Japanese yen appreciated during the sample period. The standard deviation indicates that the currency values of the Japanese yen and the new Taiwan dollar are more stable than those of the Chinese yuan and the Korean won. The average real money growth rate is the highest in China and the lowest in Japan. The average rate of inflation of Korea is much higher than those of the other three economies, while the standard deviation shows that the price level of Taiwan is less stable than that of China, Japan and Korea.

Panels A through D in Table 5 report correlation coefficients of real GDP growth, changes in the real effective exchange rate, real money balance growth, and inflation rates among the four Northeast Asian economies. Japan, Korea and Taiwan display high correlations in growth rates. The real growth rate of China is relatively separated from this group. It is only correlated with that of Taiwan. The real effective exchange rates of the four economies are relatively idiosyncratic.

Table 5. Correlation of macroeconomic variables among the Northeast Asian economies, 1971-2004

\begin{tabular}{|c|c|c|c|}
\hline & China & Japan & Korea \\
\hline \multicolumn{4}{|c|}{ Panel A: Real GDP Growth } \\
\hline China & - & & \\
\hline Japan & $-0.08(0.96)$ & - & \\
\hline Korea & $0.20(0.33)$ & $0.37(0.03)$ & - \\
\hline Taiwan & $0.33(0.09)$ & $0.62(0.00)$ & $0.42(0.01)$ \\
\hline \multicolumn{4}{|c|}{ Panel B: Real Effective Exchange Rate Growth } \\
\hline China & - & & \\
\hline Japan & $-0.17(0.41)$ & - & \\
\hline Korea & $0.21(0.30)$ & $-0.08(0.66)$ & - \\
\hline Taiwan & $0.54(0.00)$ & $-0.23(0.19)$ & $0.14(0.43)$ \\
\hline \multicolumn{4}{|c|}{ Panel C: Real Money Balance Growth } \\
\hline China & - & & \\
\hline Japan & $-0.18(0.37)$ & - & \\
\hline Korea & $-0.21(0.30)$ & $0.33(0.06)$ & - \\
\hline Taiwan & $-0.18(0.38)$ & $0.67(0.00)$ & $0.48(0.00)$ \\
\hline \multicolumn{4}{|c|}{ Panel D: Inflation } \\
\hline China & - & & \\
\hline Japan & $-0.03(0.90)$ & - & \\
\hline Korea & $-0.06(0.77)$ & $0.71(0.00)$ & - \\
\hline Taiwan & $0.04(0.84)$ & $0.80(0.00)$ & $0.71(0.00)$ \\
\hline
\end{tabular}

Note: Numbers in parentheses are p-values. 
Only China and Taiwan are correlated. For real money balance, Japan, Korea and Taiwan are highly correlated with each other, while China seems to be independent of them. Japan, Korea and Taiwan also exhibit high correlation coefficients in inflation rates. These preliminary results indicate that Japan, Korea and Taiwan have relatively higher cross-correlations in the macroeconomic environments than China. Whether or not they are ready for a currency union depends on the nature and degree of symmetry between the same-category shocks across countries, which we examine in the next section.

\section{Empirical Results}

In this section, we report the empirical results of the examining various options of a currency union and an exchange rate union in the Northeast Asia region. We also report the results of sub-sample studies to examine the impact of the 1997 Asian financial crisis on the main findings of this study.

\section{A. Currency Union}

\section{Types and the Relative Importance of Macroeconomic Shocks}

First, we examine the structure of various macroeconomic shocks in each of the four Northeast Asian economies. The ultimate purpose of forming a currency union is to stabilize economic growth in the common currency area. The shocks that can explain the most variances of real GDP growth are considered to be more important than other shocks. If shocks affecting real GDP growth are the same for all the economies, the adoption of a uniform policy can stabilize the economic growth of all the economies. If shocks affecting real GDP growth are different, a uniform policy may not stabilize the economic growth of all the economies in the region. We apply variance decomposition analysis to check the similarity of the shocks that can significantly affect real GDP growth for the four Northeast Asian economies. The results are reported in Table 6 .

For China, supply shocks are shown to explain most of the forecast error variances, up to $80 \%$, of real GDP growth, implying that supply shocks are the most important in stabilizing fluctuations in economic growth in China. This is consistent with the fact that China has become a global manufacturing center and a successful export-oriented economy. For Japan, demand shocks are the most important in the short-run, which can explain $57 \%$ of the forecast error variance of 
Table 6. Variance decomposition of real GDP growth contributed by macroeconomic shocks

\begin{tabular}{cccccc}
\hline Year & S.E & Supply Shock & Exchange Rate Shock & Monetary Shock & Demand Shock \\
\hline China & & & & & \\
1 & 0.023 & 79.69 & 8.05 & 9.19 & 3.06 \\
5 & 0.029 & 82.19 & 6.50 & 7.10 & 4.20 \\
10 & 0.029 & 81.79 & 6.44 & 7.06 & 4.72 \\
Japan & & & & & \\
1 & 0.016 & 21.39 & 10.38 & 11.51 & 56.71 \\
5 & 0.021 & 39.12 & 8.27 & 15.53 & 37.08 \\
10 & 0.021 & 39.81 & 8.15 & 15.34 & 36.70 \\
Korea & & & & & \\
1 & 0.033 & 11.46 & 19.36 & 50.22 & 18.96 \\
5 & 0.039 & 12.92 & 15.60 & 37.63 & 33.85 \\
10 & 0.039 & 15.06 & 15.21 & 36.58 & 33.14 \\
Taiwan & & & & & \\
1 & 0.025 & 38.51 & 0.68 & 13.53 & 47.28 \\
5 & 0.035 & 51.26 & 10.76 & 12.00 & 25.98 \\
10 & 0.036 & 53.15 & 10.37 & 11.41 & 25.07 \\
\hline
\end{tabular}

real GDP growth, while both supply and demand shocks become important in the long run. In Korea, monetary shocks can explain more than $50 \%$ of the forecast error variances in the short run. In the long run, both monetary shocks and demand shocks become most important in Korea. Each of the two shocks can explain more than $30 \%$ of the forecast error variance of real GDP growth in Korea. For Taiwan, both demand and supply shocks are important in the short-run. In the long-run, however, supply shocks become the most important, which can explain more than half of the total forecast error variance. This reflects Taiwan as one of the fastgrowing economies with a solid industrial base and the center of entrepreneurship activities in the region.

Variance decomposition analysis shows that the types and the temporal pattern of shocks that affect real GDP growth are very different among the four economies. A uniform monetary policy may not be able to stabilize fluctuations in real GDP growth for all the Northeast Asian economies.

\section{Adjustment Processes to Shocks}

Impulse response analysis is used to investigate the adjustment processes of the macroeconomic variables in response to different shocks in each of the four Northeast Asian economies. If the responses to shocks are shown to be similar across economies, then the adjustment processes of these economies to different 
types of shocks are expected to be similar. Then a uniform policy may be introduced to all the economies. Figures 1a-1d show the results of impulse response function analysis.

Figure 1a. Impulse response analysis of the pattern of macroeconomic shocks for China
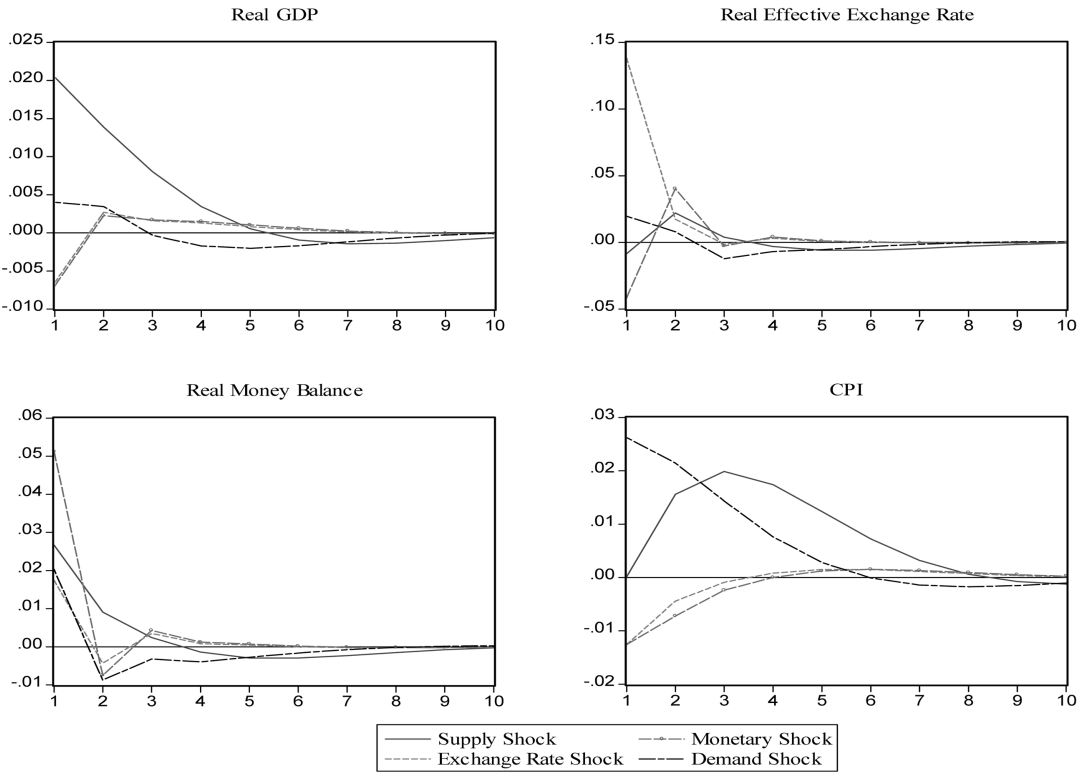

Figure 1b. Impulse response analysis of the pattern of macroeconomic shocks for Japan
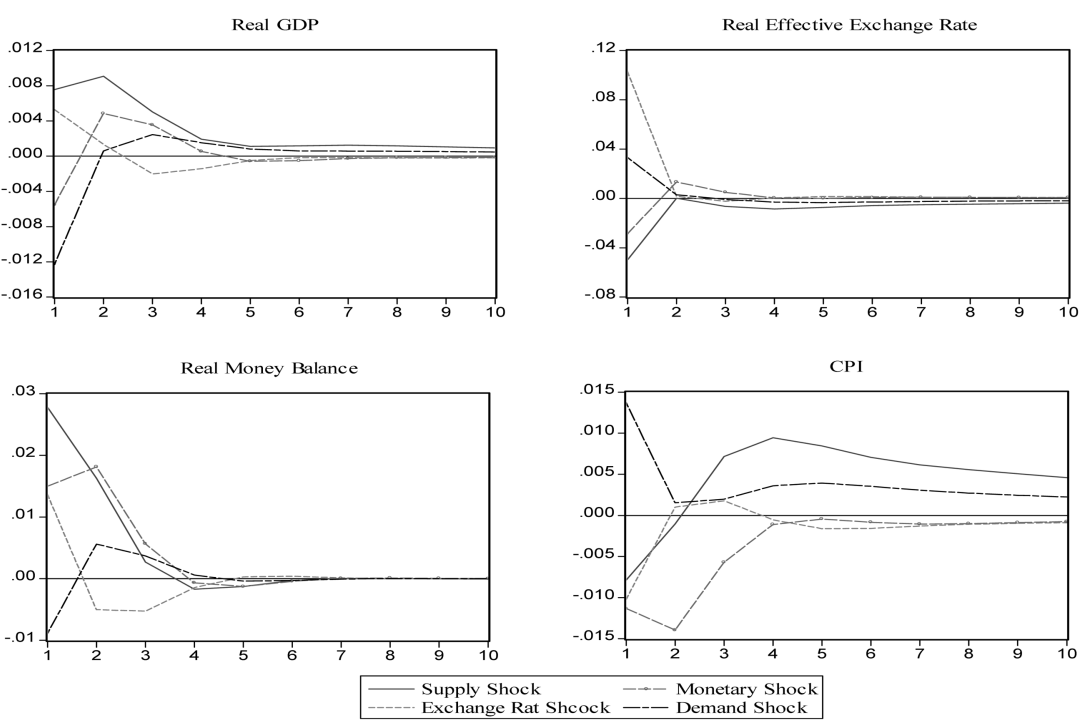
Figure 1c. Impulse response analysis of the pattern of macroeconomic shocks for Korea
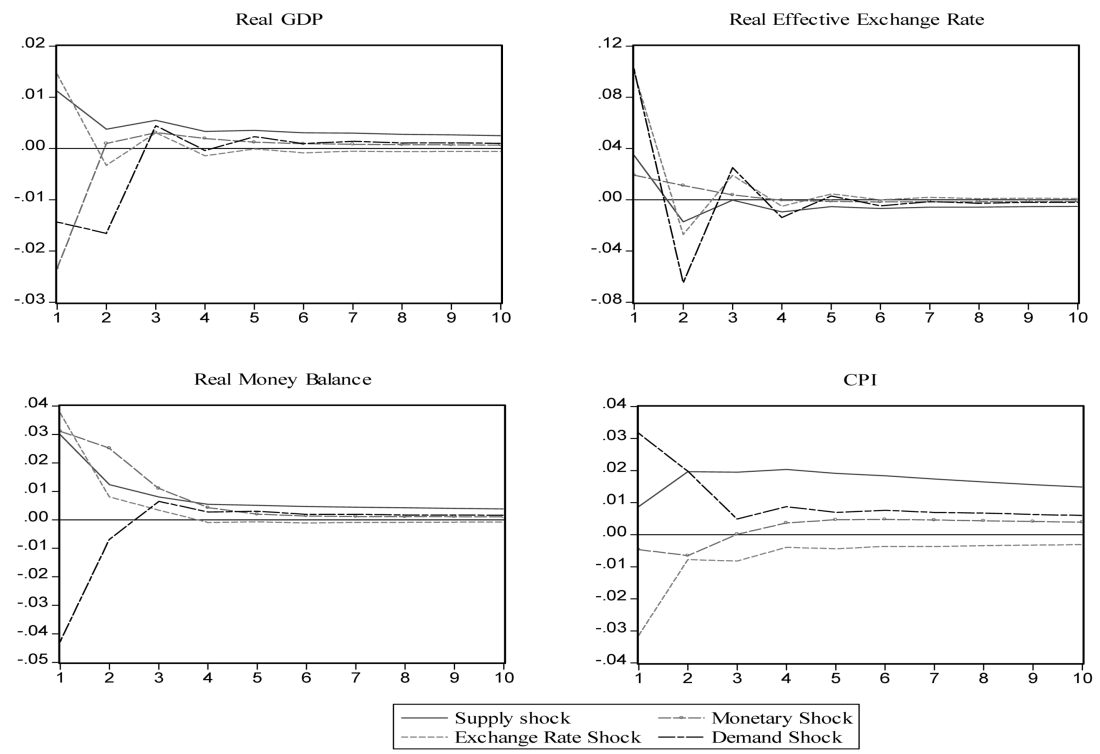

Figure 1d. Impulse response analysis of the pattern of macroeconomic shocks for Taiwan
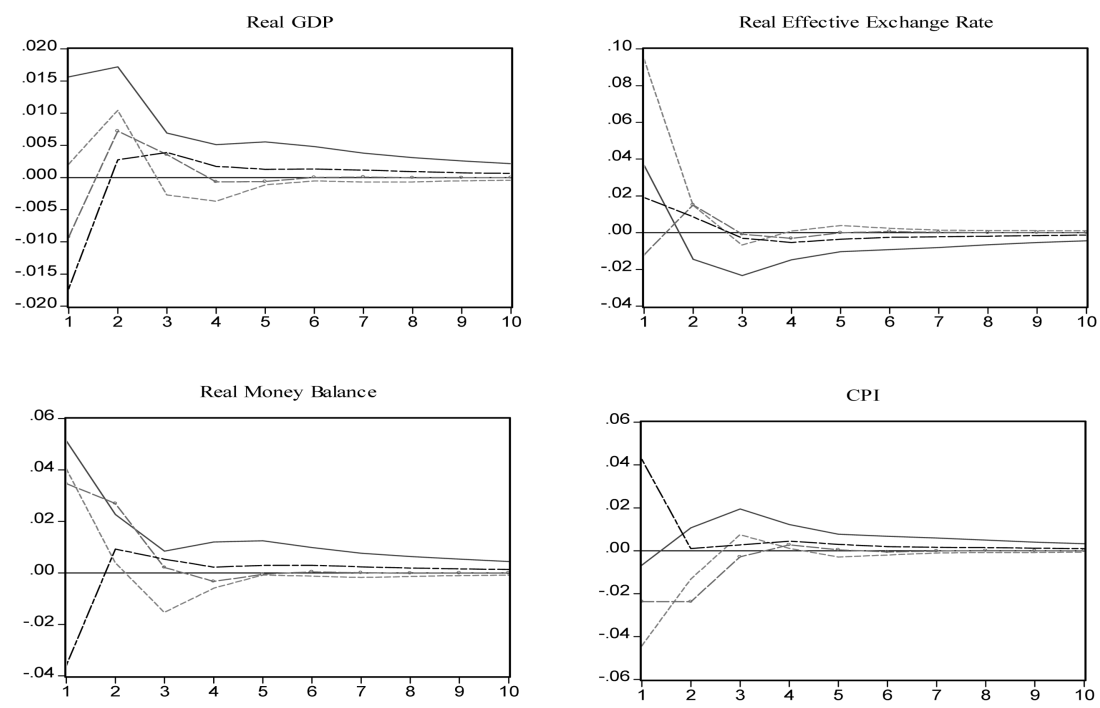

$\begin{array}{ccc}\text { Supply Shock } & \text {--- Monetary Shock } \\ --- \text { Exchange Rate Shock } & -- \text { Demand Shock }\end{array}$

It is found that positive supply shocks improve real GDP growth in the shortrun, but the effect dissipates over time. Supply shocks increase China's real GDP growth, up to four or five years, more than those of the other three economies. 
Supply shocks have similar effects on the real GDP growth of Japan, Korea and Taiwan. The effects of demand shocks and exchange rate shocks on real GDP growth of China are also different from those on the real GDP growth of Japan, Korea and Taiwan. The responses of real GDP growth to monetary shocks are similar across the four economies. Overall, the adjustment processes of real GDP growth to different types of shocks are similar among Japan, Korea and Taiwan, while the adjustment processes of China are different from the three economies conspicuously.

The responses of the real effective exchange rate of Korea and Taiwan to supply shocks are similar, while the responses of China or Japan are different. There are some similarities in the responses of the real effective exchange rate to the exchange rate shock, the monetary shock and the demand shock among China, Japan and Taiwan. The responses of the real effective exchange rate of Korea are somewhat different. It turns out that the adjustment processes of the real effective exchange rate to various shocks are different among the four economies. The adjustment processes of real money balance to various shocks are similar among Japan, Korea and Taiwan. The responses of inflation to the supply shock are similar for the China-Korea pair and the Japan-Taiwan pair. There are some similarities in the responses of inflation in the four Northeast Asian economies to the exchange rate shock and the demand shock. The reactions of inflation to the monetary shock are similar among Japan, Korea and Taiwan. However, China seems to be quite different from the other three economies.

Impulse response analysis shows that responses of real GDP growth, real effective exchange rates, real money balance, and inflation to various shocks turn out to be quite different across the four Northeast Asian economies. The different adjustment processes to various macroeconomic shocks indicate that the economic structure and the shock absorption processes lack similarities and symmetry among the Northeast Asian economies.

\section{Correlation of Shocks}

To investigate whether or not China, Japan, Korea and Taiwan can form a currency union like the Euro area, we estimate various shocks using the SVAR model. We choose one lag for all four economies, since the Akaike information criterion (AIC) and the Schwarz criterion (SC) indicate that one lag is optimal for all the economies except China. To examine the degree of symmetry of shocks, we estimated correlation coefficients of each individual shock across the Northeast 
Asian economies. If the correlation coefficients are significant and positive, the shocks are considered to be symmetric between the two economies. If the correlation coefficient is negative or insignificant, the shock is viewed as asymmetric. Table 7 reports correlation coefficients of various macroeconomic shocks between different pairs of the Northeast Asian economies.

Panel A of Table 7 reports the correlation coefficients of supply shocks among the four economies. The supply shocks are positively and significantly correlated for the Korea-Taiwan pair and Japan-Taiwan pair. The correlation coefficient between China and Japan is significant but negative. There is no other significant correlation. Since a supply shock is invariant to monetary and fiscal policies, it is considered to be more informative than other shocks (Bayoumi and Eichengreen 1994). Supply shocks of the euro area have been found to be highly correlated (e.g., Huang and Guo 2006). We see evidence, based on supply shock correlations, that Japan, Korea and Taiwan have a potential to form a currency union. China seems to be an outlier in the group, based on the correlation of supply shocks.

Table 7. Correlation of macroeconomic shocks among the Northeast Asian economies, 1971-2004

\begin{tabular}{|c|c|c|c|}
\hline & China & Japan & Korea \\
\hline \multicolumn{4}{|c|}{ Panel A: Supply shocks } \\
\hline China & - & & \\
\hline Japan & $-0.36(0.07)$ & - & \\
\hline Korea & $-0.22(0.29)$ & $0.20(0.27)$ & - \\
\hline Taiwan & $0.05(0.81)$ & $0.33(0.06)$ & $0.41(0.02)$ \\
\hline \multicolumn{4}{|c|}{ Panel B: Exchange rate shocks } \\
\hline China & - & & \\
\hline Japan & $0.07(0.73)$ & - & \\
\hline Korea & $0.09(0.65)$ & $-0.05(0.78)$ & - \\
\hline Taiwan & $0.45(0.02)$ & $0.06(0.74)$ & $0.16(0.36)$ \\
\hline \multicolumn{4}{|c|}{ Panel C: Monetary shocks } \\
\hline China & - & & \\
\hline Japan & $0.08(0.71)$ & - & \\
\hline Korea & $0.09(0.65)$ & $0.19(0.29)$ & - \\
\hline Taiwan & $-0.50(0.01)$ & $0.09(0.61)$ & $-0.07(0.69)$ \\
\hline \multicolumn{4}{|c|}{ Panel D: Demand shocks } \\
\hline China & - & & \\
\hline Japan & $-0.34(0.09)$ & - & \\
\hline Korea & $-0.08(0.71)$ & $0.27(0.13)$ & - \\
\hline Taiwan & $-0.01(0.96)$ & $0.53(0.00)$ & $0.28(0.12)$ \\
\hline
\end{tabular}

Note: Numbers in parentheses are p-values. 
Panel B of Table 7 reports the correlation coefficients of exchange rate shocks between different pairs of the Northeast Asian countries. Only the correlation coefficient between China and Taiwan is significant and positive. There is no significant correlation coefficient among other country pairs, implying that exchange rate shocks are not symmetric among these economies. This may be caused by differences in the exchange rate regime during the sample period. As shown in panel $\mathrm{C}$ of Table 7, monetary shocks are not symmetrical among China, Japan, Korea and Taiwan. As Eichengreen and Bayoumi (1996) discussed earlier, financial disturbances are an increasingly prevalent source of asymmetric shocks in Asia. Panel D of Table 7 shows the correlation coefficients of demand shocks. The Japan-Taiwan pair displays a positive and significant correlation coefficient. There are no other statistically significant correlations among these economies.

In summary, supply shocks are symmetric between Japan and Taiwan, and between Korea and Taiwan. Exchange rate shocks are symmetric between China and Taiwan. Monetary shocks are not symmetric among the Northeast Asian economies. Demand shocks are symmetric between Japan and Taiwan and marginally symmetric for the Korea-Japan pair and the Taiwan-Korea pair. The results show that there is no combination of the four economies with all four shocks symmetric.

The economic structure and shock absorption processes of these economies are evidenced to be still different. As an emerging market, China's market is still subject to intervention by the government. China's currency value is also under the control of its central bank. The Chinese yuan had been pegged to the U.S. dollar until July 2005 when it became pegged to a currency basket containing the U.S. dollar, the Japanese yen, the euro, the Korean won and other currencies. Japan, Korea and Taiwan adopt a flexible exchange rate regime. These facts seem to be some of the main reasons why China and the other three economies are subject to asymmetric shocks. Another reason is that Japan and Korea have become more integrated through economic cooperation organizations like CMI, NEAEF and free trade agreements with the ASEAN countries. Taiwan is not a member of any of these organizations. It is trade and FDI that link Taiwan with the other three economies. Statistical analysis and the condition of these economies imply that even if China, Japan, Korea and Taiwan become more integrated, it seems that the Northeast Asian economies are not ready yet to form a currency union.

The purpose of monetary cooperation is to reduce exchange rate fluctuations within the area and with the rest of the world (Eichengreen, 2006). Although it is 
still not the right time for Northeast Asia to adopt a common currency, there is other option for monetary cooperation among these economies, which is an exchange rate union. Under the exchange rate union, all currencies of the member countries will be pegged to the same anchor currency or a common currency basket. An example of an exchange rate union is the European Currency Unit (ECU). By forming an exchange rate union, the currency value is kept relatively stable within this area. They can keep their own currency although they still sacrifice some independence in monetary policy. An exchange rate union can reduce fluctuations in the currency value, trade volume and real GDP growth, although it is not as effective as a currency union because the supply of money is still determined by the central bank of each member country. When the currency index is generally accepted and used in accounting, transactions, and financial instruments, it can be developed into a single currency. An exchange rate union can be viewed as a prior stage to a currency union.

\section{Sub-sample Analysis: the impact of the 1997 Asian financial crisis}

To examine whether the financial crisis affect the result of this study, we split the sample period around 1997, and applied our structural VAR model to the period before and after 1997. ${ }^{10}$ The comparison of the whole sample and the sub-sample shows that after the crisis, correlations among the Northeast Asian economies somewhat increased.

Before the crisis, supply shocks of Japan and Taiwan are positively and significant correlated. The coefficient is higher than that of the whole sample. For the whole sample, supply shocks of Korea and Taiwan are also correlated. The correlation coefficient between China and Taiwan is smaller than that of the whole sample. So after the crisis, Taiwan became more correlated with China and Korea. The increases in the coefficient between Japan and Korea and that between Korea and Taiwan indicate that Korea has become more correlated with Japan and Taiwan after the crisis.

There is no significant correlation of exchange rate shocks before the crisis. For the whole sample, exchange rate shocks of China and Taiwan are correlated. There is no positive and significant correlation of monetary shocks. This result is similar to that of the whole sample. The coefficients of the whole sample for China, Japan, and Korea are larger than those of the sub-sample period. The improvement of

\footnotetext{
${ }^{10}$ To save the space, we do not report here the empirical results of the sub-sample study. The results are available from the authors.
} 
financial cooperation among the three countries after the crisis may be one reason for this change. For demand shocks, only Korea and Taiwan are positively and significantly correlated. For the whole sample, Japan and Taiwan are correlated. After the crisis, demand shocks of Taiwan are more correlated with those of Japan and less correlated with Korea.

The comparison of the cross-country macroeconomic shock correlations during the whole sample period and the sub-sample periods shows that the correlation relationship among the Northeast Asian economies has increased, in general, during the post- 1997 crisis period. This evidence provides a more favorable signal toward establishing an OCA in Northeast Asia.

\section{B. Exchange Rate Union}

For an exchange rate union, there are several options for the choice of an anchor currency to peg - a single currency or a common currency basket, from internal economies or external economies. If a currency or a currency basket is found for these economies, they can form an exchange rate union by jointly pegging to this currency anchor. To investigate whether the currencies of China, Japan, Korea and Taiwan can be pegged to the same currency or a common currency basket, we use the SVAR model:

$$
\Delta x_{i}=C(L) \varepsilon_{t}
$$

where $\Delta x_{t}=\left\{\Delta y_{t}^{*}, \Delta m_{t}^{*}, \Delta p_{t}^{*}, \Delta y_{t}, \Delta m_{t}, \Delta p_{t}\right\}$. The model consists of 6 variables: the real GDP $\left(y_{t}\right)$, the real money balance $\left(m_{t}\right)$, and the price level $\left(p_{t}\right)$ for domestic and foreign economices. All variables are expressed in natural logarithms. * represents a foreign variable and $\Delta$ denotes the differenced series. $C(L)$ is a $6 \times 6$ coefficient matrix with a polynomial lag operator, $L$. $\varepsilon_{t}$ is a vector containing unobserved shocks and $\varepsilon_{t}=\left\{\varepsilon_{t}^{y^{*}}, \varepsilon_{t}^{m *}, \varepsilon_{t}^{p^{*}}, \varepsilon_{t}^{v}, \varepsilon_{t}^{m}, \varepsilon_{t}^{p}\right\}$ where all the structural shocks are assumed to be orthogonal to each other. $\varepsilon_{t}^{y}, \varepsilon_{t}^{m}$, and $\varepsilon_{t}^{p}$ represent a domestic supply shock, monetary shock and demand shock, respectively, while $\varepsilon_{t}^{y}, \varepsilon_{t}^{m *}$, and denote $\varepsilon_{t}^{p *}$ a supply shock, monetary shock, and demand shock from foreign countries, respectively.

In addition to the orthogonality assumption of the structural shocks, we assume that domestic shocks do not affect foreign variables, since these economies are assumed to be small compared to the global and regional economies. It is also assumed that the demand shock and monetary shock do not affect long-run output, 
and that the demand shock does not affect the real money balance in the long run. Then the coefficient matrix, $C(L)$, can be expressed as a $6 \times 6$ lower triangular matrix of $C(L)_{i j}, i, j=1, \ldots, 6$.

Following Chow and Kim (2003) and Kim and Sun (2005), we use forecast error variance decomposition to measure the degree of symmetry of structural shocks between the economies of member nations and of the anchor currency. If shocks from foreign anchor currency countries can explain forecast error variance in real GDP growth more than a home country, then the domestic currency is better to be pegged to the anchor currency or a common currency basket. If domestic shocks are dominant, then its currency should not be pegged to the anchor currency or a common currency basket.

\section{Single Currency Peg}

First, we investigate the possibility of pegging to a single currency. Since the Northeast Asian economies mainly trade with the U.S. and Japan, the U.S. dollar and the Japanese yen are chosen as possible anchor currencies. The results of variance decomposition of real GDP contributed by macroeconomics shocks from a domestic origin and an anchor country origin are presented in Table 8 .

Panel A of Table 8 shows the results of variance decomposition when the U.S. dollar is the anchor currency. For China, the U.S. supply shock, monetary shock and demand shock together can explain more than $50 \%$ of forecast error variances of real GDP growth in both the short-run and the long-run. The forecast error variances of Japan and Korea are mainly explained by domestic specific shocks. For Taiwan, the forecast error variances of real GDP growth are mainly explained by shocks from the U.S. instead of domestic shocks. The higher explanatory power of foreign shocks implies a higher probability of pegging the domestic currency to a foreign currency. Variance decomposition analysis indicates that the Chinese yuan and the new Taiwan dollar can be pegged to the U.S. dollar, while the Japanese yen and the Korean won may not be pegged to the U.S. dollar. Panel B of Table 8 reports the results of variance decomposition when the Japanese yen is chosen as the anchor. Shocks from Japan can explain most of the forecast error variances of China and Taiwan, whereas forecast error variance is mainly explained by domestic specific shocks in Korea. So the Chinese yuan and the new Taiwan dollar can be pegged to the Japanese yen, while the Korean won can not.

China and Taiwan can peg their currencies to the U.S. dollar and the Japanese yen. But Korea cannot peg to either of the key currencies. It turns out that none of 
Table 8. Variance Decomposition of Real GDP contributed by macroeconomic shocks from a domestic origin and an anchor currency country origin: the case of exchange rate union with the U.S. dollar and the Japanese yen

Panel A: Exchange Rate Union of the U.S. Dollar

\begin{tabular}{cccccccc}
\hline Year & S.E. & $\begin{array}{c}\text { Supply } \\
\text { Shocks }\end{array}$ & $\begin{array}{c}\text { U.S. } \\
\text { Shoctary }\end{array}$ & $\begin{array}{c}\text { U.S. } \\
\text { Demand } \\
\text { Shocks }\end{array}$ & $\begin{array}{c}\text { Domestic } \\
\text { Supply } \\
\text { Shocks }\end{array}$ & $\begin{array}{c}\text { Domestic } \\
\text { Monetary } \\
\text { Shocks }\end{array}$ & $\begin{array}{c}\text { Domestic } \\
\text { Demand } \\
\text { Shocks }\end{array}$ \\
\hline China & & & & & & & \\
1 & 0.022 & 14.59 & 39.49 & 2.13 & 33.42 & 8.66 & 1.71 \\
5 & 0.030 & 15.87 & 35.90 & 2.03 & 38.05 & 6.89 & 1.27 \\
10 & 0.030 & 15.96 & 35.92 & 2.03 & 37.95 & 6.87 & 1.27 \\
Japan & & & & & & & \\
1 & 0.016 & 1.91 & 15.25 & 4.38 & 24.27 & 16.09 & 38.10 \\
5 & 0.022 & 1.78 & 12.50 & 14.04 & 31.65 & 17.07 & 22.97 \\
10 & 0.022 & 1.74 & 12.12 & 16.54 & 30.74 & 16.55 & 22.31 \\
Korea & & & & & & & \\
1 & 0.036 & 1.05 & 10.15 & 2.214 & 68.21 & 17.06 & 1.32 \\
5 & 0.041 & 2.47 & 12.96 & 3.85 & 60.73 & 18.64 & 1.35 \\
10 & 0.041 & 4.23 & 12.76 & 4.23 & 59.25 & 18.20 & 1.33 \\
Taiwan & & & & & & & \\
1 & 0.026 & 0.24 & 48.92 & 16.50 & 1.74 & 22.83 & 9.78 \\
5 & 0.035 & 10.06 & 30.59 & 14.12 & 20.19 & 17.03 & 8.01 \\
10 & 0.036 & 9.50 & 29.45 & 18.73 & 18.91 & 15.92 & 7.49
\end{tabular}

Panel B: Exchange Rate Union of the Japanese Yen

\begin{tabular}{cccccccc}
\hline Year & S.E. & $\begin{array}{c}\text { Japan } \\
\text { Supply } \\
\text { Shocks }\end{array}$ & $\begin{array}{c}\text { Japan } \\
\text { Monetary } \\
\text { Shocks }\end{array}$ & $\begin{array}{c}\text { Japan } \\
\text { Demand } \\
\text { Shocks }\end{array}$ & $\begin{array}{c}\text { Domestic } \\
\text { Supply } \\
\text { Shocks }\end{array}$ & $\begin{array}{c}\text { Domestic } \\
\text { Monetary } \\
\text { Shocks }\end{array}$ & $\begin{array}{c}\text { Domestic } \\
\text { Demand } \\
\text { Shocks }\end{array}$ \\
\hline China & & & & & & & \\
1 & 0.019 & 57.67 & 0.82 & 14.32 & 22.69 & 0.01 & 4.49 \\
5 & 0.033 & 34.49 & 14.61 & 28.46 & 17.54 & 2.44 & 2.46 \\
10 & 0.036 & 29.70 & 17.81 & 28.05 & 14.42 & 6.56 & 3.48 \\
Korea & & & & & & & \\
1 & 0.036 & 9.67 & 6.26 & 13.49 & 56.31 & 13.58 & 0.69 \\
5 & 0.040 & 8.01 & 11.50 & 13.75 & 49.86 & 15.91 & 0.98 \\
10 & 0.040 & 8.53 & 11.43 & 13.87 & 49.42 & 15.77 & 0.98 \\
Taiwan & & & & & & & \\
1 & 0.026 & 17.08 & 5.34 & 26.80 & 19.40 & 28.46 & 2.92 \\
5 & 0.034 & 23.67 & 13.48 & 18.16 & 17.18 & 24.27 & 3.26 \\
10 & 0.035 & 25.19 & 13.26 & 18.21 & 16.65 & 23.51 & 3.19 \\
\hline
\end{tabular}

the two major currencies can be chosen as a currency anchor for the potential exchange rate union including all four economies. A single currency peg does not seem to be a feasible choice for these Northeast Asian economies. 
On the other hand, pegging to a single currency may be risky. The experience of the crisis of 1997 shows that the fluctuations in the yen-dollar rate cause instability in the trade balance of Japan's competitors that peg their currencies to the U.S. dollar. The Chinese yuan was pegged to the U.S. dollar and switched to a currencybasket peg in July 2005. The evidence indicates that a single currency peg does not seem to be a good choice for the four economies. Since neither the U.S. dollar nor the Japanese yen turns out to be an option for a common anchor currency for the Northeast Asian economies, we examine whether or not a currency basket is a reasonable option as an anchor currency for them.

\section{Regional Currency Basket}

In order to explore a possibility of pegging to a regional basket, we use a VAR model with Cholesky triangularization of variance-covariance matrix for China, Korea and Taiwan. For Japan, we use the Vector Error Correction (VEC) model because all of the series are I(1) and there are cointegration relationships among the series for Japan. The sample period is from 1977 to 2005 . The regional macroeconomic variables are constructed using the geometric averages of the variables of all four Northeast Asian economies. The weight is the relative size of the economy, which is the share of real GDP ${ }^{11}$.

The results of variance decomposition are reported in Table 9. The forecast error variance of China is mainly explained by the domestic supply shock in the short run. In the long run, however, regional shocks become more important, explaining more than half of total forecast error variances. For Japan, the forecast error variance is mostly explained by regional shocks. In Korea, regional shocks and domestic shocks explain the forecast error variance almost equally. To the contrary, the forecast error variance of Taiwan is mainly explained by domestic supply shocks in the short run. But in the long run the percentage explained by regional shocks increases over time. Overall, it is shown that the currencies of all four Northeast Asian economies can be pegged to the regional currency basket in the long run. This provides evidence that the regional currency basket whose weights in the currency basket are determined by the share of real GDP can be used as the anchor for the exchange rate union in the region.

For the common currency basket to be effective, a system like the European

\footnotetext{
${ }^{11}$ The share of each currency is as follows: the Chinese yen $11.2 \%$, the Japanese yen $79.2 \%$, the Korean won $6.1 \%$, and the new Taiwan dollar 3.5\%. For a more detailed discussion about different weighting schemes for regional currency units such as ECU and ACU, see Moon et al. (2006).
} 
Table 9. Variance decomposition of real GDP growth contributed by various macroeconomic shocks originated from the domestic economy and other economies in the region: the case of the exchange rate union with a regional currency basket

\begin{tabular}{cccccccc}
\hline Year & S.E. & $\begin{array}{c}\text { Segional } \\
\text { Shocks }\end{array}$ & $\begin{array}{c}\text { Regional } \\
\text { Monetary } \\
\text { Shocks }\end{array}$ & $\begin{array}{c}\text { Regional } \\
\text { Demand } \\
\text { Shocks }\end{array}$ & $\begin{array}{c}\text { Domestic } \\
\text { Supply } \\
\text { Shocks }\end{array}$ & $\begin{array}{c}\text { Domestic } \\
\text { Monetary } \\
\text { Shocks }\end{array}$ & $\begin{array}{c}\text { Domestic } \\
\text { Demand } \\
\text { Shocks }\end{array}$ \\
\hline China & & & & & & & \\
1 & 0.019 & 23.70 & 0.45 & 6.48 & 69.36 & 0.00 & 0.00 \\
5 & 0.033 & 18.40 & 12.45 & 18.62 & 42.30 & 4.02 & 4.21 \\
10 & 0.036 & 18.55 & 13.05 & 20.80 & 35.14 & 5.80 & 6.67 \\
Japan & & & & & & & \\
1 & 0.011 & 84.95 & 0.69 & 3.07 & 11.29 & 0.00 & 0.00 \\
5 & 0.019 & 32.56 & 41.49 & 2.28 & 15.00 & 8.32 & 0.35 \\
10 & 0.020 & 29.67 & 38.83 & 4.46 & 15.80 & 9.43 & 1.81 \\
Korea & & & & & & & \\
1 & 0.036 & 41.29 & 1.77 & 7.35 & 49.59 & 0.00 & 0.00 \\
5 & 0.046 & 32.27 & 10.65 & 8.11 & 31.57 & 9.96 & 7.44 \\
10 & 0.0466 & 32.22 & 11.17 & 8.01 & 30.91 & 10.13 & 7.55 \\
Taiwan & & & & & & & \\
1 & 0.023 & 3.83 & 2.38 & 28.29 & 65.51 & 0.00 & 0.00 \\
5 & 0.031 & 8.97 & 8.14 & 20.49 & 40.80 & 14.65 & 6.96 \\
10 & 0.034 & 9.87 & 8.36 & 25.82 & 35.05 & 13.88 & 7.02 \\
\hline
\end{tabular}

Exchange Rate Mechanism (ERM) needs to be established to allow a limited band of fluctuation of a member currency around the parity. It is unlikely that such a system can be established in the near future until regional shocks gain a more important role than domestic shocks in the region, especially in the short-run horizon.

\section{Major External Currency Basket}

The U.S. dollar is still the most-used invoicing currency in international trade in East Asia. At the same time, the Northeast Asian economies trade a lot with the U.S., Japan and the euro area. The fluctuation of exchange rates against these key currencies can significantly affect their exports and imports. A major currency basket containing the U.S. dollar, the Japanese yen, and the euro may also serve as an anchor currency for the Northeast Asian economies.

We obtain the macroeconomics variables of the currency basket countries as the geometric average of the variables from the three major economies, the U.S., Japan, and the euro area. The weight is the share of trade with all four Northeast 
Asian economies for two periods, 1990-1993 and 1997-2003 ${ }^{12}$. The SVAR model ${ }^{13}$ is used for China, Korea, and Taiwan. For Japan, a VAR model with Cholesky triangularization of variance-covariance matrix is used since the assumption that domestic variables do not affect foreign variables does not hold for Japan.

The results are reported in Table 10. For China, Japan and Korea, in the short run, the forecast error variance is explained more by domestic shocks than external shocks, while Taiwan shows almost equal shares between domestic and external shocks. Although the shares explained by foreign shocks increase a little over time, domestic shocks and foreign shocks seem to play a similar role in explaining forecast error variances of real GDP growth in the region.

The variance decomposition indicates that the four Northeast Asian economies may not be worse off if they peg to the currency basket containing the major

Table 10. Variance decomposition of real GDP growth contributed by various macroeconomic shocks originated from the domestic economy and external economies: the case of the exchange rate union with a major external currency basket

\begin{tabular}{cccccc}
\hline Year & S.E. & $\begin{array}{c}\text { External Supply } \\
\text { Shocks }\end{array}$ & $\begin{array}{c}\text { External Demand } \\
\text { Shocks }\end{array}$ & $\begin{array}{c}\text { Domestic Supply } \\
\text { Shocks }\end{array}$ & $\begin{array}{c}\text { Domestic } \\
\text { Demand Shocks }\end{array}$ \\
\hline China & & & & & \\
1 & 0.032 & 0.00 & 42.37 & 56.89 & 0.74 \\
5 & 0.034 & 0.69 & 47.65 & 50.98 & 0.68 \\
10 & 0.035 & 1.13 & 48.81 & 49.38 & 0.68 \\
Japan & & & & & \\
1 & 0.018 & 31.15 & 5.52 & 63.33 & 0.00 \\
5 & 0.022 & 40.79 & 3.87 & 46.87 & 8.48 \\
10 & 0.022 & 40.80 & 3.93 & 45.86 & 9.42 \\
Korea & & & & & \\
1 & 0.032 & 30.81 & 12.30 & 12.58 & 44.31 \\
5 & 0.041 & 25.70 & 22.64 & 10.76 & 39.90 \\
10 & 0.042 & 25.91 & 24.09 & 10.32 & \\
Taiwan & & & & & 5.68 \\
1 & 0.031 & 48.14 & 1.09 & 45.55 & 7.36 \\
5 & 0.035 & 45.44 & 3.57 & 43.63 & \\
10 & 0.035 & 45.84 & 4.85 & 42.19 & \\
\hline
\end{tabular}

\footnotetext{
${ }^{12}$ Data for 1994-1996 are dropped because of missing data. The share of the U.S. is $52.2 \%$; the share of the Japanese yen is $21.4 \%$; and the share of the Euro is $26.4 \%$.
${ }^{13}$ Only supply shocks and demand shocks are examined, because the data of M2 for European countries are not available.


external currencies. Pegging to this currency basket helps to stabilize the currency value within the exchange rate union as well as the exchange rates against the currencies of the major trading partners. So the currency basket of the major external currencies is expected to promote both intra-regional trade and trade with countries outside this area.

Compared with the internal, regional currency basket, the major external currency basket has the advantage that it can reduce fluctuations exchange rates between the four currencies in the region and currencies of the major trading partners outside the region. The central banks of the four Asian economies should hold additional foreign reserves in the currencies of the currency basket, no matter which currency basket they choose (Eichengreen 2006). If they peg to a regional currency basket, they have to hold foreign reserves in other three currencies in the region. Neither of them, except the Japanese yen, is the major currency in foreign reserves, especially the Chinese yuan, the Korean won, and the new Taiwanese dollar. Before adopting the local currency basket, they have to enhance the convertibility and global status of their currencies. For the present, the major currency basket anchor seems to be a more suitable option for the exchange rate union adopted by the Northeast Asian economies. In the long run, however, with the increase in intra-regional trade and a more integrated economy, a regional currency basket should become a better choice.

\section{Conclusion and Policy Implications}

Although several studies have claimed that certain combinations of the East Asian countries are eligible for a common currency area, these combinations contain both the Northeast Asian economies and the ASEAN countries. It is unlikely that these countries will form a common currency area and adopt a uniform monetary policy in the near future because of divergence in the political environment, economic standards and cultural background. China, Japan, Korea, and Taiwan are the major economies of Northeast Asia. They have significantly increased economic and financial linkages among them in recent years with successful globalization efforts and relatively similar cultural backgrounds, ongoing and conflicting political agenda notwithstanding. It seems to be more feasible for these Northeast Asian economies to form a currency union or a collective pegging than other Southeastern Asian countries.

In this paper, we apply the SVAR model with proper identification assumptions 
imposed on time-series data for the period from 1970 to 2004 and investigate the possibility of a currency union or an exchange rate union among the Northeast Asian economies. Variance decomposition indicates that the fluctuations of real GDP growth of the four economies are affected by different shocks. Impulse response analysis suggests that the adjustment processes to various shocks are different across economies. The analysis of the correlation between supply, exchange rate, monetary, and demand shocks shows that the macroeconomic shocks of these economies are far from symmetric. All these empirical results provide ample evidence that Northeast Asia is not ready yet to form a common currency union at least in the near future. Japan, Taiwan and Korea have a potential to form a currency union in the long run. China is still separated from this group because its economic structure and the shock adjustment mechanism turn out to be quite different from those in other three economies. ${ }^{14}$

Although Northeast Asia is not a common currency area yet, China, Japan, Korea, and Taiwan may form an exchange rate union, where each economy still has its own currency and all of the currencies are pegged to the same anchor currency or a common currency basket. Variance decomposition analysis suggests that both the regional currency basket, which consists of all four Northeast Asian currencies, and the major external currency basket, which consists of the US dollar, the Japanese yen and the euro, can be adopted as the anchor for the exchange rate union. The major external currency basket should be a better choice for the short run because it can stabilize both exchange rates within the region and exchange rates with the major trading partners outside the region. It is also because regional currencies are not attractive enough yet to be major foreign reserve currencies. With an increase in intra-regional trade and further financial integration, however, a regional currency basket will be a more suitable option in the long run.

The Asian Development Bank (ADB) announced to introduce the Asian Currency Unit (ACU) in early 2006. Like the European Currency Unit (ECU), the ACU is also a basket of regional currencies, and it provides participating countries with a regional benchmark for monitoring and stabilizing their currency values against major external currencies. The ECU was first adopted as a unit of account,

\footnotetext{
${ }^{14} \mathrm{~A}$ simple examination of historic data, such as this study, may underestimate a country's readiness to enter a currency union, since the OCA criteria may be endogenous. Frankel and Rose (1998) provide evidence that there is a strong positive relationship between the intensity of bilateral trade and the cross-country correlation of business cycle activities. Accordingly, a country which enters a currency union is expected to enhance the synchronicity in business cycles and the symmetry in macroeconomic shocks across countries in the OCA region.
} 
while the ACU will be used as an indicator of the stability of the regional currencies. Unlike the ECU, it is not likely that the ACU will be used as money in transactions in the foreseeable future. However, the introduction of the ACU helps to stabilize the exchange rate and promote intra-regional trade and investment. Based on the idea of the ECU and the ACU, a currency basket containing all four regional currencies, the Chinese yuan, the Japanese yen, the Korean won, and the new Taiwan dollar, can be considered as an anchor currency.

An exchange rate union of pegging to a common currency basket, from internal or external, is only an intermediate stage. As the Northeast Asian economies become more integrated, the regional currency basket can serve as a currency unit for the area, similar to the ECU. The Northeast Asian economies have taken efforts to achieve this goal. The possibility of establishing Northeast Asian Development Bank (NEADB) and the Northeast Asia Free Trade area is currently discussed. They improve cooperation in both economic and financial aspects through forming the Northeast Asia Economic Forum (NEAEF) and extending an international reserve asset swap networking such as Chiang Mai Initiative (CMI). When the area has a more fully integrated goods market, financial market, labor market, and a more similar economic structure with a symmetric shock adjustment mechanism across countries in the region, the regional currency unit can develop into a single common currency. At that stage, the four Northeast Asian economies will give up their independent monetary policies and a central bank for the region would be established. The Northeast Asian economies need to enhance macroeconomic convergence and increase financial and monetary cooperation until they reach the stage of introducing a Northeast Asian currency union in the future.

\section{Acknowledgements}

Earlier versions of this paper have been presented at the 2006 EEA annual meeting, Philadelphia, February 2006, and the Global Finance Conference, Rio de Janeiro, Brazil, April 2006. The authors thank the editor and referee of this Journal, the session participants and Alina Luca, Maria Olivero, Vibhas Madan, and Jay Choi for their helpful comments and suggestions. 


\section{References}

Asian Development Bank. (2004). Monetary and Financial Integration in East Asia: The Way Ahead, Vol. 1, ed., ADB, New York, NY: Palgrave Macmillan.

Bayoumi, T., Eichengreen, B. (1994). One Money or Many? Analyzing the Prospects for Monetary Unification in Various Parts of the World. Princeton Studies in International Finance, No. 76, Princeton University.

Bénassy-Quéré, A. (1999). "Optimal Pegs for East Asian Currencies

Bhandari, J. (1985). "The flexible exchange basket: a macroeconomic analysis," Journal of International Money and Finance 1, 19-41.

Blabchard, O. and Quah, D. (1989). "The dynamic effects of aggregate demand and supply disturbances," American Economic Review 79, 655-673.

Cheung, Y. and Yuen, J. (2004). "An output perspective on a Northeast Asia currency union," Prospects for Monetary Unions after the Euro, ed. P. Grauwe and J. Mélitz. Cambridge: The MIT Press.

Chow, H. K. and Kim, Y. (2003). "A common currency peg in East Asia? Perspectives from Western Europe," Journal of Macroeconomics 25, 331-350.

Eichengreen, B. and Bayoumi, T. (1996). "Is Asia an optimum currency area? Can it become one? Regional, global and historical perspectives on Asian monetary relations," CEPII/AMUE/KDI Conference in Exchange Rate Policies in Emerging Asian Countries, Seoul.

Eichengreen, B., (2006). "The parallel currency approach to Asian monetary integration," 2006 AEA conference paper.

Frankel, J.A. and Rose, A.K. (1998). "The endogeneity of the optimum currency area criteria," The Economic Journal 108(July), 1009-1025.

Huang, Y. and Guo, F. (2006). "Is currency union a feasible option in East Asia? A multivariate structural VAR approach," Research in International Business and Finance 20(1), 77-94.

Karras, G. (2005). "Is there a yen optimum currency area? Evidence from 18 Asian and Pacific economies," Japan and the World Economy 17, 456-469.

Kawai, M. and Takagi, S. (2000). "Proposed strategy for a regional exchange rate arrangement in post-crisis East Asia," The World Bank Policy Research Working Paper 2503.

Kenen, P. B. (1969). "The theory of optimum currency areas," Monetary Problems of the International Economy, ed. R. A. Mundell and A. K. Swoboda. Chicago: The University of Chicago Press.

Kim, Y. and Sun, W. (2005). "Asymmetric shocks and the choice of exchange rate regimes in East Asia," unpublished manuscript.

Kwack, S. Y. (2004). "An optimum currency area in East Asia: Feasibility, coordination, and leadership role," Journal of Asian Economics 15, 153-169.

Kwan, C. (2000). The Yen Block: Toward Economic Integration in Asia. Brooking 
Institution Press, Washington D.C.

Larrain, F. and Tavares, J. (2005). "Regional currencies versus dollarization: options for Asia and the Americas," Prospects for Monetary Unions after the Euro, ed., P. Grauwe and J. Melitz. Cambridge: The MIT Press.

Lee, J-W. and Barro, R.J. (2006). "East Asian Currency Union," working paper, October.

Lim, L. (2005). "A dollar or yen currency union in East Asia," Mathematics and Computers in Simulation 68, 505-518.

McKinnon, R. I. (1963). “Optimum currency areas," American Economic Review 51, 717724.

McKinnon, R. I. (2000). "After the crisis, the East Asian dollar standard resurrected: An interpretation of high-frequency exchange-rate pegging," Rethinking the East Asian Miracle, ed. J. Stiglitz and S. Yusuf. World Bank and Oxford University Press.

McKinnon, R.I., Pill, H. (1999). "Exchange-rate regimes for emerging markets: Moral hazard and international overborrowing," Oxford Review of Economic Policy 15, 1938.

Moon, W., Rhee, Y., and Yoon, D. (2006). Regional Currency Unit in Asia: Property and Perspective, Korea Institute for International Economic Policy (KIEP) Working Paper 06-03, Seoul, Korea.

Mundell, R. (1961). "A theory of optimum currency areas," American Economic Review $51,657-665$.

Ogawa, E., Ito, T. (2002). "On the desirability of a regional basket currency arrangement," Journal of the Japanese and International Economics 16, 317-334.

Sakakibara, E., Yamakawa, S. (2003). "Regional integration in East Asia: challenge and opportunity-Part II: Trade, Finance and Integration," The World Bank Policy Research Working Paper 3079.

Schnabl, G. (2005). "Synchronized business cycles in East Asia and fluctuations in the yen/dollar exchange rate," Exchange Rates under the East Asian Dollar Standard: Living with Conflicted Virtue, ed. R. McKinnon. Cambridge: The MIT Press.

Zhang, Z., Sato, K. (2005). "Whither currency union in greater China?" Center for International Trade Studies Working Paper, 2005-01.

Zhang, Z., Sato, K., McAleer, M. (2004). "Is a monetary union feasible for East Asia?" Applied Economics 36, 1031-1043. 